\title{
SYNTHESIS, CHARACTERIZATION, DFT MODELING AND IN VITRO ANTIMYCOBACTERIAL ACTIVITY ASSAYS OF A SILVER(I)-ISONIAZID COMPLEX
}

\section{José Alberto Paris Juniora, Maurício Cavicchiolib**, Rachel Temperani Amaral Machado ${ }^{\mathrm{c}}$, Fernando Rogério Pavan Douglas Hideki Nakahata ${ }^{d}$, Pedro Paulo Corbi ${ }^{d}$, Adão Marcos Ferreira Costa ${ }^{\mathrm{e}}$, Douglas Henrique Pereira ${ }^{\mathrm{e}}$ and Antonio Carlos Massabnia, (1)}

aUniversidade de Araraquara, 14801-320 Araraquara - SP, Brasil

'Departamento de Química Analítica, Físico-Química e Inorgânica, Instituto de Química, Universidade Estadual Paulista "Júlio de Mesquita Filho", 14800-900 Araraquara - SP, Brasil

"Departamento de Ciências Biológicas, Faculdade de Ciências Farmacêuticas, Universidade Estadual Paulista "Júlio de Mesquita Filho", 14800-903 Araraquara - SP, Brasil

'Instituto de Química, Universidade Estadual de Campinas, 13083-970 Campinas - SP, Brasil

eUniversidade Federal do Tocantins, Campus Gurupi, Gurupi - TO, Brasil

Recebido em 22/07/2020; aceito em 03/11/2020; publicado na web em 01/12/2020

\begin{abstract}
In the present work, a silver(I) complex with the antimycobacterial drug isoniazid (inh) is described. Elemental and thermogravimetric analyses confirmed a 1:1 metal:ligand ratio for the silver-isoniazid (Ag-inh) complex with molecular composition $\mathrm{AgC}_{6} \mathrm{H}_{7} \mathrm{~N}_{3} \mathrm{O} \cdot \mathrm{NO}_{3}$. Infrared (IR) analysis suggests a bidentate coordination of isoniazid to silver by the nitrogen of the $\mathrm{NH}_{2}$ group and by the oxygen of the $\mathrm{C}=\mathrm{O}$ group, and also confirms the presence of free nitrate anion. Coordination by the $\mathrm{NH}_{2}$ group was reinforced by $\mathrm{NMR}$ measurements. Computational simulations using the density functional theory (DFT) reinforced that the ligand coordinates to the silver atom by the $\mathrm{NH}_{2}$ and $\mathrm{C}=\mathrm{O}$ groups. The silver complex presented a minimal inhibitory concentration $\left(\mathrm{MIC}_{90}\right.$ ) of $0.78 \mu \mathrm{g} / \mathrm{mL}$ against the standard Mycobacterium tuberculosis strain H37Rv. The data reported herein warrants further investigation on Ag-inh complex as a potential agent against tuberculosis.
\end{abstract}

Keywords: metallodrugs; bioinorganic chemistry; molecular modeling; Mycobacterium tuberculosis; antibacterial assays.

\section{INTRODUCTION}

There are about 1.5 million deaths annually due to tuberculosis (TB), which remains as a remarkable public health issue, causing concern worldwide. Globally, the best estimate is that 10 million people (range 9.0-11.1 million) developed TB in 2018: $57 \%$ of all TB cases are diagnosed in men, $32 \%$ in women and $11 \%$ in children. ${ }^{1}$ The number of infections is growing up, especially in immunosuppressed patients (HIV), and in individuals with diabetes or receiving antitumor drugs.

Despite the improvement of TB treatment, it is severely affected by the appearance of multidrug-resistant Mycobacterium tuberculosis strains. ${ }^{2}$ According to the World Health Organization Global Tuberculosis Report, ${ }^{1}$ the best worldwide estimate is that, in 2018, about half a million people have developed TB resistance to rifampicin (RR-TB), the most effective first-line anti-TB drug. More alarming is that, within this group, 78\% developed multidrug-resistant TB (MDR-TB). So, urgent actions are required to improve the coverage and quality of diagnosis, treatment and care for people with drugresistant TB. These actions include the search of new drugs. ${ }^{3}$

Modification of old drugs is a strategy that can improve bioavailability and tolerability, which can decrease the resistance of pathogenic strains. ${ }^{4}$ Coordination of metal ions to drugs is a way to modify their chemical characteristics and consequently modify their pharmacokinetics, pharmacodynamics and mechanism of action on the bacteria. ${ }^{5,6}$

Isoniazid (Figure 1), also called isonicotinic acid hydrazide (inh), was discovered in 1912, but its anti-TB activity was only reported on 1951. It belongs to the group of drugs called "first-line antimycobacterial

\footnotetext{
*e-mail: mauriciocavicchioli@gmail.com
}

drugs", which includes rifampicin (RIF), pyrazinamide (PZA) and ethambutol (ETH). The molecule has a heterocyclic $\mathrm{N}$-atom of the pyridine ring and $\mathrm{O}$ - and $\mathrm{N}$-atoms of the hydrazide group. Such coordination sites make inh an interesting ligand from the viewpoint of coordination chemistry.<smiles>NNC(=O)c1ccncc1</smiles>

Figure 1. Structural formula of isoniazid (inh)

There are some reports of the synthesis of metal complexes with isoniazid in the literature. Cobalt and copper complexes with isoniazid were prepared by Hanson and Poggi. ${ }^{7}$ Their studies suggest that the metal is coordinated to inh by the nitrogen atom of the $\mathrm{NH}_{2}$ group and the oxygen atom of the carbonyl group. Diniz et al. described a zinc(II) complex bound to two inh molecules, which also contains six hydration water molecules and two perchlorate counter-ions for each metal center. Zinc(II) adopts a distorted octahedral geometry, where two inh molecules is coordinated in a bidentate manner by the hydrazide group $(\mathrm{N}, \mathrm{O})$ and the other two inh residues complete the coordination sphere of zinc(II) binding to the aromatic nitrogen atoms. ${ }^{8}$ The authors also described mixed ligand complexes of $\mathrm{Co}(\mathrm{II})$, $\mathrm{Zn}(\mathrm{II})$ and $\mathrm{Mg}(\mathrm{II})$ containing inh as one of the ligands. ${ }^{9,10}$ Both complexes are coordination polymers.

Silver complexes and nanoparticles have also been considered in the search for novel active compounds against bacteria. Silver and several of its compounds have long been used as antimicrobial agents in medicine. ${ }^{11-16}$ The $\mathrm{Ag}(\mathrm{I})$ sulfadiazine complex, for instance, has been used clinically as an antibacterial and antifungal agent since the 
1960s. It is an insoluble polymeric compound that slowly releases $\mathrm{Ag}(\mathrm{I})$ ions and is applied topically as a cream to prevent bacterial infections in cases of severe burns. ${ }^{11-14,17}$

Initially, some studies have suggested that the primary target for inhibition of bacterial and yeast growth by silver(I) complexes is due to their binding to proteins containing S-donor ligands, and not nucleic acids as N/O donors..$^{13,18,19}$ So, silver(I) complexes with $\mathrm{N}$ - and $\mathrm{O}$-donor molecules have increased the ability to replace such molecules by the S-donor ligands of target bacterial proteins. Recently, it has been shown that silver ions target glyceraldehyde-3phosphate dehydrogenase of the glycolytic pathway in E. coli, binding to cysteine and histidine residues in an almost linear geometry. ${ }^{20}$ The most recent and broader investigation was done by $\mathrm{H}$. Wang et al. ${ }^{21}$ The combined data from metalloproteomics and metabolomics indicated that $\mathrm{Ag}^{+}$exerts its antimicrobial activity against $E$. coli by targeting important metabolic and physiological pathways. Primarily, $\mathrm{Ag}^{+}$damages multiple enzymes in glycolysis and tricarboxylic acid (TCA) cycle, leading to the stalling of the oxidative branch of the TCA cycle and an adaptive metabolic divergence to the reductive glyoxylate pathway. This further damages the adaptive glyoxylate pathway and suppresses the cellular oxidative stress responses, causing systemic damages and death of the bacterium. As an example of these modifications, the levels of adenosine monophosphate (AMP), inosine-5'-monophosphate (IMP), hypoxanthine, guanosine, and uridine, which are involved in nucleic acid degradation or synthesis, decreased after $\mathrm{Ag}^{+}$exposure.

The activity of silver complexes and formulations over tuberculosis is an emerging and promising field of research. Strong antimycobacterial activity against multi-drug-resistant M. tuberculosis of silver-carrying photocatalyst products was verified by Matsui et al. ${ }^{22}$ The development of strategies to modify an old drug and/or the combination of consolidated drugs, such as antibiotics, with metal ions with already known antimicrobial activities can lead to new and improved antibacterial agents. More recently, silver(I) complexes of fluoroanthranilic acid isomers were described in the literature and showed minimal inhibitory concentration $\left(\mathrm{MIC}_{90}\right)$ values around $10 \mu \mathrm{mol} \mathrm{L} \mathrm{L}^{-1}$ against $M$. tuberculosis $\mathrm{H} 37 \mathrm{Rv}$ bacterial strain, which are lower than the $\mathrm{MIC}_{90}$ observed for the free ligands and silver nitrate. ${ }^{23}$

Although no silver(I)-isoniazid complexes have been reported in the literature, a recent study showed that an inh and silver nitrate mixture with no isolation of the complex has a potent bactericidal effect on isoniazid-resistant clinical $M$. tuberculosis strains, resulting in lower MIC values than those from the isolate components. The authors claimed that the increased activity may be a result from an additive activity due to the increased production of reactive oxygen species by the combination treatment, which leads to oxidative stress and bacterial cell death. ${ }^{24}$

In the present work a silver(I) complex with the first-line antimycobacterial drug isoniazid is described. The complex was synthesized, isolated and characterized by spectroscopic techniques and density functional theory (DFT) calculations, and its antimycobacterial properties were evaluated against the standard Mycobacterium tuberculosis strain H37Rv.

\section{EXPERIMENTAL}

\section{Materials}

Isoniazid and silver(I) nitrate were analytical grade products from Sigma/Aldrich chemical company. All other chemicals are analytical grade products from different sources. The reagents were used as received.

\section{Synthesis}

The silver complex with isoniazid was prepared by the addition of $10 \mathrm{~mL}$ of an aqueous solution containing $0.850 \mathrm{~g}(5.0 \mathrm{mmol})$ of silver(I) nitrate to $10 \mathrm{~mL}$ of an aqueous solution containing $0.685 \mathrm{~g}$ (5.0 mmol) of isoniazid under stirring in a dark room. Initially the solution changed to white and then a brownish precipitate was formed. The solid was collected by filtration, washed with water and left to dry in a desiccator with $\mathrm{P}_{4} \mathrm{O}_{10}$ in a dark room. Anal. Calc. for $\left[\mathrm{Ag}\left(\mathrm{C}_{6} \mathrm{H}_{7} \mathrm{~N}_{3} \mathrm{O}\right)\right] \cdot \mathrm{NO}_{3}(\%), \mathrm{C} 23.5, \mathrm{H} 2.3, \mathrm{~N}$ 18.3. Found (\%) C 22.8, $\mathrm{H} 1.73, \mathrm{~N} 18.8$. No single crystals were obtained to perform a full X-ray crystallographic study.

\section{Instrumental methods}

Elemental analyses of carbon, hydrogen and nitrogen were performed using a CHNS-O 2400 series II (Perkin Elmer) Analyzer. High purity cysteine was used as a reference substance. Infrared (IR) spectra were recorded on a FT-IR Cary 630 Agilent Spectrophotometer, equipped with attenuated total reflectance (ATR) sampling apparatus. The resolution was set at $4 \mathrm{~cm}^{-1}$. Thermal analysis was performed on a Thermoanalyzer TG/DTA simultaneous SDT Q-600 TA Instruments under the following conditions: $\alpha$-alumina crucible, synthetic air $(100 \mathrm{~mL} / \mathrm{min})$, heating rate of $10^{\circ} \mathrm{C}$ per min, from 30 to $1000{ }^{\circ} \mathrm{C}$. Solution-state ${ }^{1} \mathrm{H}$ and ${ }^{13} \mathrm{C}$ nuclear magnetic resonance (NMR) spectra for free inh and its silver complex were recorded on Bruker AVANCE III 400 and $500 \mathrm{MHz}$ spectrometers. The NMR spectra were acquired in deuterated dimethyl sulfoxide (dmso-d6) solutions and chemical shifts were given relative to tetramethylsilane (TMS).

\section{Anti-Mycobacterium tuberculosis analysis}

Resazurin microtiter assay (REMA) was used to determine the $\mathrm{MIC}_{90}$ of compounds against the standard Mycobacterium tuberculosis strain H37Rv. Briefly, the compounds were diluted in Middlebrook $7 \mathrm{H} 9$ broth, supplemented with OADC, and $0.5 \%$ glycerol. The solutions, in a range concentration of 0.09 to $25 \mu \mathrm{g} \mathrm{mL}^{-1}$, were added to a 96-well microplate with the bacterial inoculum,

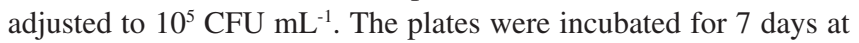
$37^{\circ} \mathrm{C}, 5.0 \% \mathrm{CO}_{2}$ atmosphere. A solution of Resazurin was added at $0.01 \%$ in water and after incubation of $24 \mathrm{~h}$, the fluorescence was read at 530/590 $\mathrm{nm}$. Three biological replicates were performed. The $\mathrm{MIC}_{90}$ was defined as the lowest concentration of compound able to inhibit $90 \%$ of mycobacterial growth. ${ }^{25}$

\section{Computational simulations}

The density functional theory (DFT) was used to study the ligand and the silver complex. The possible structures of isoniazid and the Ag-inh complex $\left[\mathrm{Ag}\left(\mathrm{C}_{6} \mathrm{H}_{7} \mathrm{~N}_{3} \mathrm{O}\right)\right] \mathrm{NO}_{3}$ were optimized to the minimum of energy with the hybrid functional B3LYP. ${ }^{26-29}$ The $6-31+\mathrm{G}(\mathrm{d}, \mathrm{p})^{30,31}$ basis sets was used for $\mathrm{C}, \mathrm{H}, \mathrm{N}$ and $\mathrm{O}$ atoms. For the Ag-atom, the LANL2DZ ${ }^{32}$ effective core potential basis set was used. Vibrational frequencies were calculated, and no imaginary frequencies were found, showing that the structures were at their minimum energy. All calculations were performed using the software Gaussian 09. ${ }^{33}$ The topological analyses of the complexes were performed using the quantum theory of atoms in molecules (QTAIM) ${ }^{34,35}$ at the B3LYP/6$31+\mathrm{G}(\mathrm{d}, \mathrm{p}) /$ LANL2DZ level. The QTAIM allows to characterize the chemical bond of the metal with the ligand and also to understand the nature of the bond. The QTAIM analyses were performed using the AIMALL package. ${ }^{36}$ 


\section{RESULTS AND DISCUSSION}

\section{Infrared spectroscopic analysis}

The IR spectra of inh and the silver complex are presented in Figure 2. The main IR frequencies in the region $3500-600 \mathrm{~cm}^{-1}$ are shown in Table 1 . The IR of inh is in accordance with the literature. ${ }^{37}$
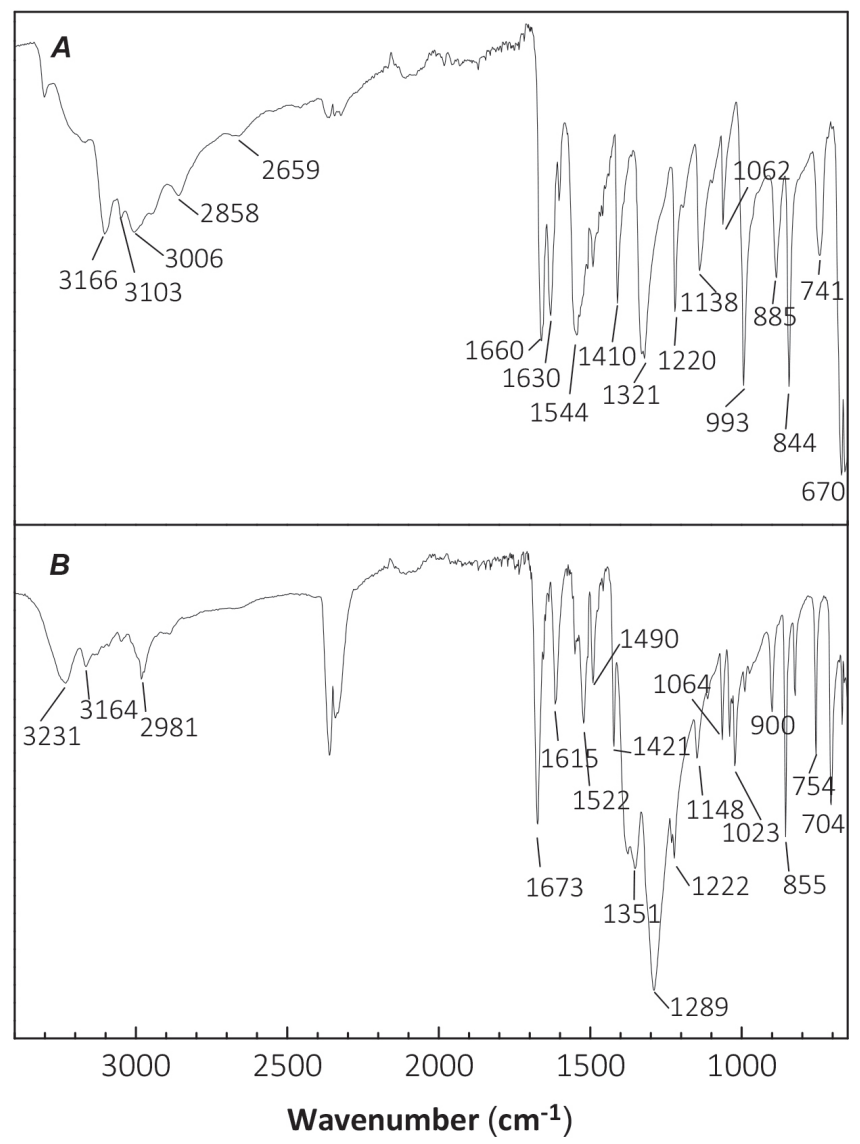

Figure 2. Infrared spectra of A) isoniazid (inh) and B) Ag-inh

Several IR bands of isoniazid had their frequencies changed after coordination to $\mathrm{Ag}(\mathrm{I})$. Among them, the band related to $\mathrm{NH}_{2}$ wagging at $1630 \mathrm{~cm}^{-1}$ shifted to $1615 \mathrm{~cm}^{-1}$ in the complex and the band related to $\mathrm{C}=\mathrm{O}$ at $1660 \mathrm{~cm}^{-1}$ was shifted to $1673 \mathrm{~cm}^{-1}$ in the complex. The changes observed when the IR spectra of the ligand and the Ag-inh complex are compared suggest coordination of the ligand to the metal by the nitrogen atom of the $\mathrm{NH}_{2}$ group and also coordination by the oxygen atom of the $\mathrm{C}=\mathrm{O}$ group. ${ }^{38}$

Regarding the $v(\mathrm{C}-\mathrm{N})$ amide-like and the $v(\mathrm{~N}-\mathrm{N})$ bands, a similar behavior was observed for the Co-inh complex early reported in the literature. The coordination affects only the amide-like stretching mode. Finally, the strong band at $1289 \mathrm{~cm}^{-1}$ in the spectrum of the metal complex confirms the presence of free $\mathrm{NO}_{3}{ }^{-}$as a counterion. ${ }^{39}$

\section{Thermogravimetric measurements}

Figure 3 shows the thermogravimetric curve for the Ag-inh complex, with three well defined weight losses. The first loss of about $38 \%$ occurs in the range $140-200{ }^{\circ} \mathrm{C}$. The other two mass losses occur in the ranges $200-280{ }^{\circ} \mathrm{C}$ and $320-360{ }^{\circ} \mathrm{C}$ which correspond to the decomposition of the ligand and the $\mathrm{NO}_{3}{ }^{-}$anion. The thermogravimetric curve shows a net weight loss of about $62 \%$, with a final residue of $38 \%$, which is consistent with the formation of $\mathrm{Ag}^{\circ}$.
Table 1. Main IR frequencies $\left(\mathrm{cm}^{-1}\right)$ of inh and the Ag-inh complex

\begin{tabular}{ccc}
\hline isoniazid (inh) & Ag-inh complex & Vibrational assignments \\
\hline 670 & 704 & $\tau(\mathrm{C}-\mathrm{C}-\mathrm{C})_{\text {ring }}+\tau(\mathrm{C}-\mathrm{N}-\mathrm{C}-\mathrm{C})_{\text {ring }}$ \\
741 & 754 & $\delta$ ring \\
844 & 855 & $\gamma(\mathrm{C}-\mathrm{C}-\mathrm{H})$ \\
885 & 900 & $\gamma(\mathrm{C}-\mathrm{C}-\mathrm{H})_{\text {ring }} ; \delta(\mathrm{C}=\mathrm{O})$ \\
993 & 1023 & $\gamma(\mathrm{C}-\mathrm{C}-\mathrm{H}) ; \gamma\left(\mathrm{NH}_{2}\right)$ \\
1062 & 1064 & $\delta$ ring \\
1138 & 1148 & $v(\mathrm{~N}-\mathrm{N}-\mathrm{H}) \mathrm{s}$ \\
1220 & 1222 & $\delta(\mathrm{C}-\mathrm{H})$ \\
& 1289 & $v N \mathrm{~N}_{3}$ \\
1321 & 1351 & $v(\mathrm{C}-\mathrm{N})_{\text {amide }}, \delta\left(\mathrm{NH}_{2}\right)$ \\
1410 & 1422 & $v$ ring \\
1485 & 1490 & $v$ ring \\
1545 & 1523 & $v$ ring; $\mathrm{wN}^{-\mathrm{N}-\mathrm{H}}$ \\
1630 & 1615 & $w N \mathrm{H}_{2}$ \\
1660 & 1673 & $v(\mathrm{C}=\mathrm{O})$ \\
$3000-3100$ & $3000-3100$ & $v(\mathrm{C}-\mathrm{H})$ \\
3166 & 3164 & $v\left(\mathrm{NH}^{2}\right)$ \\
3303 & 3223 & $v\left(\mathrm{NH}_{2}\right)$ \\
\hline
\end{tabular}

$v$ : stretching; $\beta$ : in plane bending; $\gamma$ : out of plane bending; S: scissoring; $\tau$ : torsion; w: wagging.

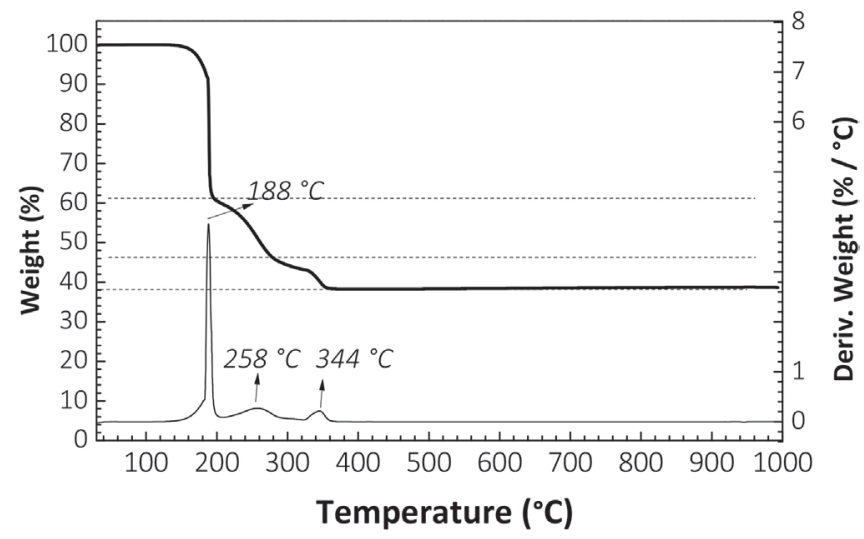

Figure 3. Thermogravimetric curves (TG and DTG) of the Ag-inh complex

Differential scanning calorimetry (DSC) analysis of the Ag-inh complex (see Figure 1S, Supplementary Material) indicates the occurrence of three exothermic events with their maxima at 190, 275 and at $348{ }^{\circ} \mathrm{C}$, which correspond likely to oxidation of the ligand leading to the formation of silver residue.

\section{Nuclear magnetic resonance spectroscopy}

The ${ }^{1} \mathrm{H}$ and ${ }^{13} \mathrm{C}$ NMR spectra of the silver complex were evaluated in comparison to the spectra of free isoniazid to confirm the coordination sites of the ligand to the metal as suggested by the IR data.

The ${ }^{1} \mathrm{H}$ NMR spectra of inh and its Ag complex are presented in Figure 4 together with the numbered ligand structure. The most notable change in the spectrum of the metal complex when compared to the spectrum of the ligand is the signal from the hydrogen atoms of the $\mathrm{NH}_{2}$ group (numbered as $\mathrm{H} 7$ ). The spectrum of the ligand shows a sharp signal at $4.64 \mathrm{ppm}$ for the $\mathrm{H}$-atoms of the $\mathrm{NH}_{2}$ group. Upon 
coordination, the same $\mathrm{H}$-atoms are detected as a broad signal shifted downfield, with its maximum at $5.59 \mathrm{ppm}(\Delta \delta$ 0.95). In addition, the $\mathrm{H}$-atom of the $\mathrm{N}-\mathrm{H}$ group (H6) bonded to the $\mathrm{NH}_{2}$ is also shifted downfield by $0.31 \mathrm{ppm}$, which reinforces the coordination of the $\mathrm{NH}_{2}$ group of inh to $\mathrm{Ag}(\mathrm{I})$.

The analysis of the ${ }^{13} \mathrm{C}$ NMR spectra of inh and its silver complex (Figure 1S, Supplementary Material) did not permit us to confirm coordination of the ligand to silver by the $\mathrm{O}$ atom of the carbonyl group as first suggested by the IR data. No significant isomer shifts were detected when comparing the signal of the $\mathrm{C}$ atom of the carbonyl group in the ligand at $163.88 \mathrm{ppm}$ with the same $\mathrm{C}$ atom in the complex, which was observed at $164.05 \mathrm{ppm}$. Also, the absence of significant changes in the signals of carbon atoms $\mathrm{C}_{2,2}, \mathrm{C}_{3,3}$, or $\mathrm{C}_{4}$ (see Figure 1S, Supplementary Material) led us to discard $\mathrm{N}$ coordination of the pyridine ring of inh to Ag.

Nevertheless, considering that the infrared spectroscopic data suggested nitrogen of the $\mathrm{NH}_{2}$ group and also oxygen coordination of the $\mathrm{C}=\mathrm{O}$ group to silver and that this coordination mode was already observed for a $\mathrm{Cu}$ (II) complex with inh, further studies based on DFT (see next section) were applied to evaluate if this bidentate coordination mode would in fact exist and if it would be the most stable one.

\section{Molecular modeling}

Due to the absence of crystals of the Ag-inh complex to perform a detailed X-ray crystallographic study and considering the possible coordination sites of inh to Ag suggested by IR and NMR spectroscopic measurements, DFT studies were performed to evaluate some possibilities of complexation. Such possibilities evaluated were calculated according to Figure 5.

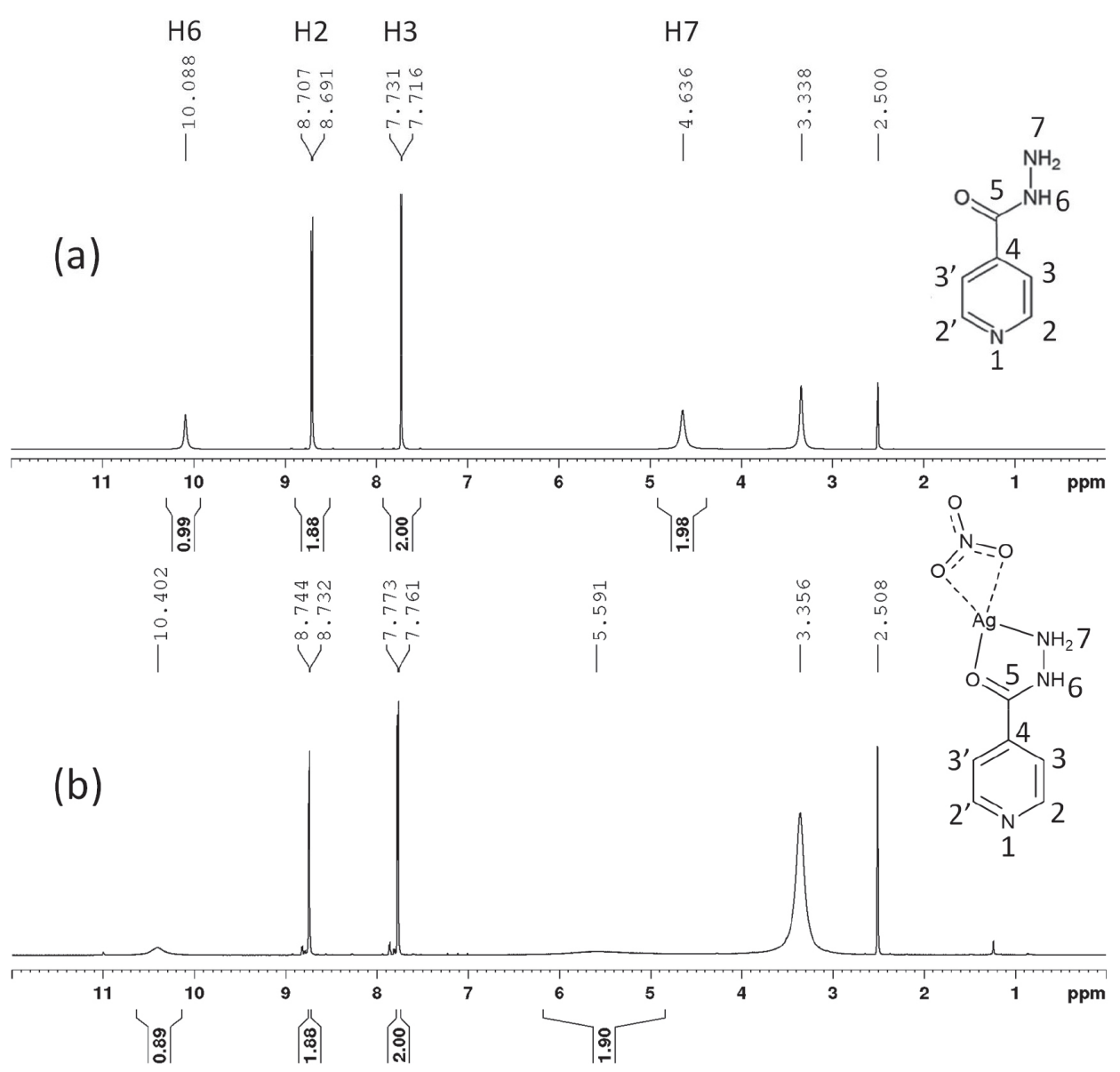

Figure 4. ${ }^{I} H$ NMR spectra of (a) isoniazid and $(b)$ silver complex
Analyzing the theoretical results of four possible complexation sites, it is possible to infer that the structure where ligand coordination to $\mathrm{Ag}$ atom occurs by the $\mathrm{N}$ atom of the $\mathrm{NH}_{2}$ group and oxygen atom of the group $\mathrm{C}=\mathrm{O}$ (Figure $5 \mathrm{~d}$ ) is the most stable one. The ligand coordination to $\mathrm{Ag}$ atom only by the nitrogen of the $\mathrm{NH}_{2}$ group, Figure 5a, is the second most stable structure. The difference in the stability between metal complexes (Figure 5d and 5a) is small and on the order of $1.3 \mathrm{kcal} \mathrm{mol}^{-1}$. On the other hand, the structure proposed on Figure 5b, where coordination was suggested to occur by the $\mathrm{NH}$ and $\mathrm{NH}_{2}$ groups, shows that after the optimization of geometry the structure converges to the first hypothesis (Figure 5a). Finally, analyzing the complexation by the $\mathrm{NH}$ group (Figure 5c), it is possible to identify that the interaction occurs, but this is less stable because there is a steric hindrance for the ligand coordination to silver by the NH group. The difference in stability of complex (Figure 5c) in relation to the most stable complex is $11.16 \mathrm{kcal} \mathrm{mol}^{-1}$ and in relation to the complex represented in Figure 5a the difference is $9.86 \mathrm{kcal} \mathrm{mol}^{-1}$.

After determining the most stable structure, it is possible to analyze properties of the complex such as the optimal bond lengths $\mathrm{N} \cdots \mathrm{Ag}$ and $\mathrm{O} \cdots \mathrm{Ag}$ which were 2.60 and $2.30 \AA$, respectively. The coordination mode of inh to $\mathrm{Ag}(\mathrm{I})$ is the same observed for the $\mathrm{Cu}(\mathrm{II})$ complex with this ligand early reported. ${ }^{40}$

Another structural property that can be analyzed for coordination bonds is the vibrational frequencies. The values of the vibrational frequencies $\mathrm{wNH}_{2}$ and $v(\mathrm{C}=\mathrm{O})$ theoretically determined for the ligand were 1707 and $1740 \mathrm{~cm}^{-1}$, respectively. The vibrational frequencies of the bonds decrease with coordenation and the values found were $1679 \mathrm{~cm}^{-1}$ for $\mathrm{wNH}_{2}$ and $1722 \mathrm{~cm}^{-1}$ for $\mathrm{v}(\mathrm{C}=\mathrm{O})$. It is important to emphasize that no scale factor was used to correct the error associated 
a)

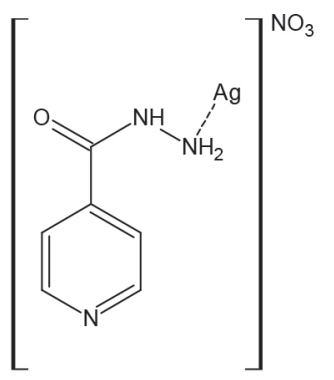

b)

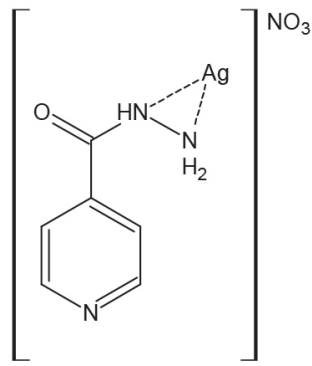

c)

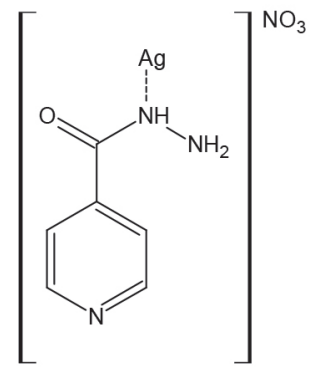

d)<smiles>O=[N+]([O-])[O-]</smiles>

Figure 5. Simulated coordination modes of inh to Ag

with the calculation method, which justifies the difference in relation to the experimental data.

The QTAIM was used to better understand the electronic effects of the Ag-inh complex. In QTAIM analysis, the nature of the bond or interaction can described by some parameters such as electronic density $(\rho(r))$, Laplacian of electronic density $\left(\nabla^{2} \rho(r)\right)$, and total electronic energy $(\mathrm{H}(\mathrm{r}))(\mathrm{H}(\mathrm{r})=\mathrm{G}(\mathrm{r})+\mathrm{V}(\mathrm{r}))$. According to QTAIM, values of $\nabla^{2} \rho(r)<0$ indicate covalent bonds and $\nabla^{2} \rho(r)>0$ indicate noncovalent bonds. When the values of $\nabla^{2} \rho(r)$ and $H(r)$ are positive, the nature of the interaction or bond is electrostatic, for $\nabla^{2} \rho(r)$ positive and $\mathrm{H}(\mathrm{r})$ negative the bond are considered partially covalent. ${ }^{34,35}$

The results for the QTAIM analysis for the Ag-N and Ag-O bonds are shown in Figure 6 along with the molecular graph of the complex. The values of $\nabla^{2} \rho(r)$ is positive and $H(r)$ is negative for the Ag-O bond showing that the bond has partially covalent character. For the Ag-N the values of $\nabla^{2} \rho(r)$ and $H(r)$ are positive showing that the bond has an electrostatic character.

\section{Anti-Mycobacterium tuberculosis activity}

The Ag-inh complex was active against $M$. tuberculosis with a $\mathrm{MIC}_{90}$ of $0.78 \pm 0.5 \mu \mathrm{g} \mathrm{mL}^{-1}\left(2.55 \mu \mathrm{mol} \mathrm{L}^{-1}\right)$. Although the Ag complex presents a $\mathrm{MIC}_{90}$ value higher than rifampicin $\left(0.08 \pm 0.02 \mu \mathrm{g} \mathrm{mL}^{-1}\right)$ and inh itself $\left(0.13 \pm 0.06 \mu \mathrm{g} \mathrm{mL} \mathrm{L}^{-1}\right.$ or $\left.0.948 \mu \mathrm{mol} \mathrm{L}^{-1}\right)$, it is lower than other antimycobacterial agents used in TB clinical treatments as ethambutol $\left(\mathrm{MIC}_{90}=5.62 \mu \mathrm{g} \mathrm{mL}^{-1}\right)$ and $\mathrm{p}$-aminosalicylic $\left(\mathrm{MIC}_{90}=1.25 \mu \mathrm{g} \mathrm{mL}^{-1}\right)$. It is well established that free inh is a potent and selective prodrug that inhibits the biosynthesis of the mycobacteria cell wall by interrupting the synthesis of mycolic acids. It is called a prodrug because it just becomes active after a transformation by a catalase-peroxidase enzyme, giving rise to isonicotinic acid. ${ }^{41}$ The rigidity and stability conferred to the complex by the silver atom could prevent the biotransformation of inh to isonicotinic acid and thus inhibit its activity but only additional studies could confirm or not this hypothesis. It was observed that the Ag-inh is active against M. tuberculosis and similar results were published in the literature with cobalt and copper complexes with isoniazid complexes, which have shown to be active against $M$. tuberculosis with $\mathrm{MIC}_{90}$ values of $0.41 \mu \mathrm{mol} \mathrm{L}-1$ and $2.2 \mu \mathrm{mol} \mathrm{L}^{-1}$, respectively. Also, The $\mathrm{MIC}_{90}$ value was below the maximum limit of $25 \mu \mathrm{g} \mathrm{mL} \mathrm{mL}^{-1}$, which is the value described in the literature that warrants for further studies of active compounds against $M$. tuberculosis. Montelongo-Peralta et al. ${ }^{24}$ reported a study showing that an inh and $\mathrm{Ag}$ nitrate mixture, with no isolation of the complex, has a potent bactericidal effect on inhresistant clinical $M$. tuberculosis strains, resulting in lower MIC values than those from the isolate components. However, the resulting MIC of $\mathrm{AgNO}_{3}$ in the mixture was higher (around $10.0 \mu \mathrm{mol} \mathrm{L}{ }^{-1}$ ) than that of the isolated Ag-isoniazid complex presented in this study $(2.55 \mu \mathrm{mol} \mathrm{L}-1)$.

Ahmed et $a l .{ }^{42}$ studied the antimicrobial activity of a phenanthroline-isoniazid hybrid ligand (L) and its $\mathrm{Ag}^{+}$and $\mathrm{Mn}^{2+}$ complexes. The authors found that $\left[\mathrm{Ag}(\mathrm{L})_{2}\right] \mathrm{BF}_{4},\left[\mathrm{Ag}(\mathrm{L})_{2}\right] \mathrm{NO}_{3} \cdot 2 \mathrm{H}_{2} \mathrm{O}$ and $\left[\mathrm{Mn}(\mathrm{L})_{2}\right]\left(-\mathrm{NO}_{3}\right)_{2} \cdot 2 \mathrm{H}_{2} \mathrm{O}$, were almost fourfold more potent than inh. Curiously, there was no real variation in activity across the group of metal complexes, suggesting that activity was independent of the type of chelated central metal ion $\left(\mathrm{Ag}^{+}\right.$and $\left.\mathrm{Mn}^{2+}\right)$.

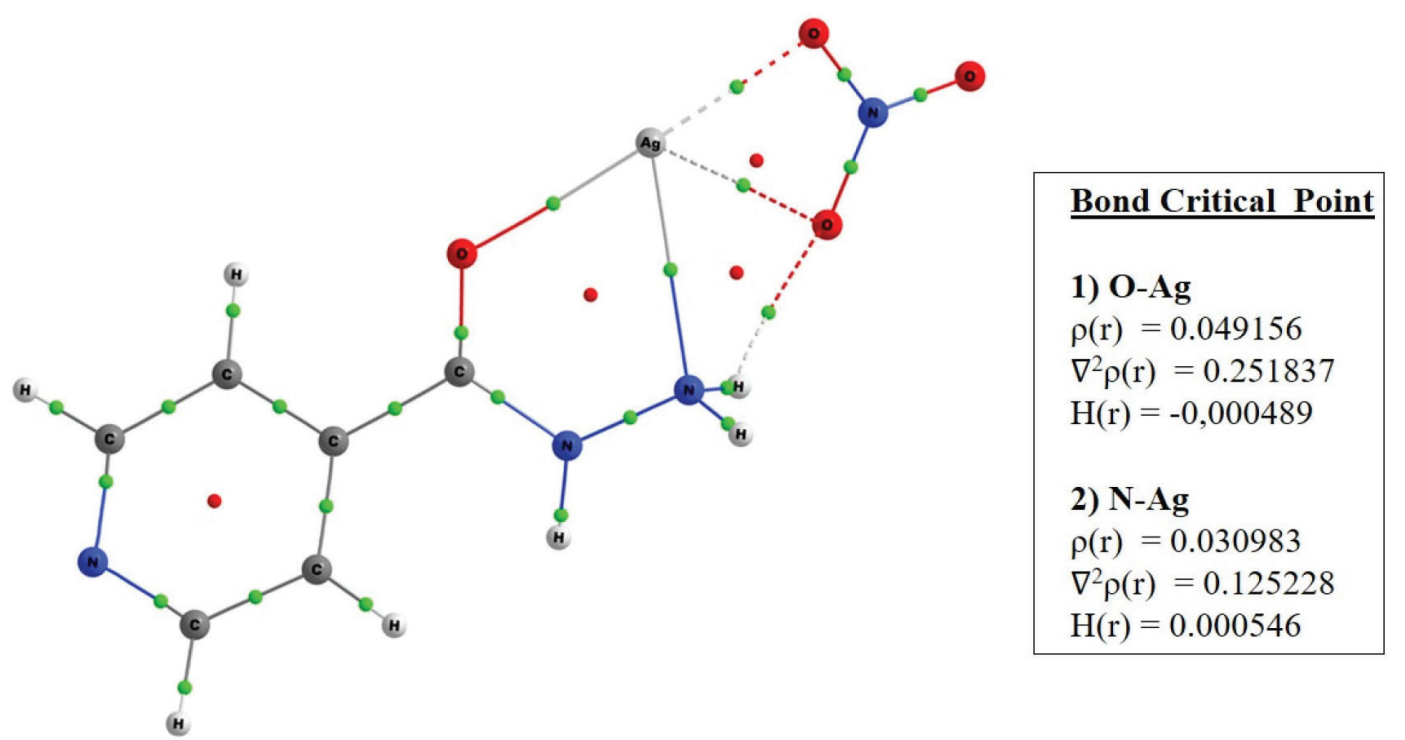

Figure 6. Molecular graph for $\left[\mathrm{Ag}\left(\mathrm{C}_{6} \mathrm{H}_{7} \mathrm{~N}_{3} \mathrm{O}\right)\right] \mathrm{NO}_{3}$ and topological parameter $\rho(r), \nabla^{2} \rho(r)$ and $H(r)$ for $\mathrm{Ag}-\mathrm{N}$ and Ag-O bonds generated by $Q T A I M$. Bond critical points are represented by yellow circles, red circles are the ring critical points and the values of topological properties are in au 


\section{CONCLUSIONS}

A new silver complex with isoniazid, with coordination formula $\left[\mathrm{Ag}\left(\mathrm{C}_{6} \mathrm{H}_{7} \mathrm{~N}_{3} \mathrm{O}\right)\right] \cdot \mathrm{NO}_{3}$, was obtained. Infrared spectroscopic analysis permitted proposing coordination of the ligand to $\mathrm{Ag}$ by the $\mathrm{N}$ atom of the $\mathrm{NH}_{2}$ group and oxygen atom of the $\mathrm{C}=\mathrm{O}$ group. The ${ }^{1} \mathrm{H} \mathrm{NMR}$ spectroscopic measurements reinforced $\mathrm{N}$ coordination of $\mathrm{NH}_{2}$ to the metal. The structures of inh and the Ag-inh complex were optimized to the minimum of energy using the density functional theory (DFT). The studies confirmed that the coordination mode where inh coordinates to $\mathrm{Ag}(\mathrm{I})$ by the nitrogen atom of $\mathrm{NH}_{2}$ group and also by the $\mathrm{O}$ atom of $\mathrm{C}=\mathrm{O}$ group is the most stable one. Bond lengths of $\mathrm{N} \cdots \mathrm{Ag}$ and $\mathrm{O} \cdots \mathrm{Ag}$ were 2.60 and $2.30 \AA$, respectively. The Ag-inh complex was active over M. tuberculosis with $\mathrm{MIC}_{90}$ of $0.78 \pm 0.5 \mu \mathrm{g} \mathrm{mL}^{-1}\left(2.55 \mu \mathrm{mol} \mathrm{L}^{-1}\right)$. Further analyses are envisaged to verify this hypothesis and ensure its potential as a drug candidate for the treatment of tuberculosis.

\section{SUPPLEMENTARY MATERIAL}

DSC and ${ }^{13} \mathrm{C}$-NMR spectra for inh and the Ag complex are freely available at http://quimicanova.sbq.org.br in PDF format.

\section{ACKNOWLEDGMENTS}

This study was supported by grants from the Brazilian Agencies FAPESP (São Paulo State Research Council, Grants No. 2015/208823, 2017/11570-3 and 2018/12062-4). Douglas H. Pereira also acknowledges the Center for Computational Engineering and Sciences (Financial support from FAPESP, Grants No. 2013/08293-7 and 2017/11485-6) and the National Center for High Performance Processing (CENAPAD) in São Paulo for the computational resources. This study was partially financed by the Coordenação de Aperfeiçoamento de Pessoal de Nível Superior - Brasil (CAPES) Finance Code 001.

\section{REFERENCES}

1. WHO. Global Tuberculosis Report 2019, 2019, WHO: France.

2. Cardoso, R. F.; Cooksey, R. C.; Morlock, G. P.; Barco, P.; Cecon, L.; Forestiero, F.; Leite, C. Q. F.; Sato, D. N.; Shikama, M. D.; Mamizuka, E. M.; Hirata, R. D. C.; Hirata, M. H.; Antimicrob. Agents Chemother. 2004, 48, 3373.

3. Vaerewijck, M. J. M.; Huys, G.; Palomino, J. C.; Swings, J.; Portaels, F.; FEMS Microbiol. Rev. 2005, 29, 911.

4. Domingos, S.; André, V.; Quaresma, S.; Martins, I. C. B.; Minas da Piedade, M. F.; Duarte, M. T.; J. Pharm. Pharmacol. 2015, 67, 830.

5. Ames, J. R.; Ryan, M. D.; Kovacic, P.; J. Free Radicals Biol. Med. 1986, 2,377 .

6. Sarkar, K.; Sen, K.; Int. J. Pharm. Sci. Res. 2015, 6, 1.

7. Poggi, M.; Barroso, R.; Costa, A. J.; Barros, H. B.; Pavan, F. R.; Leite, C. Q.; Gambino, D.; Torre, M. H.; J. Mex. Chem. Soc. 2013, 57, 198.

8. Freitas, M. C. R.; António, J. M. S.; Ziolli, R. L.; Yoshida, M. I.; Rey, N. A.; Diniz, R.; Polyhedron 2011, 30, 1922.

9. Almeida, F. B.; Cunha, M. S.; Abreu, H. A.; Diniz, R.; ChemistrySelect 2016, 1, 3770 .

10. Almeida, F. B.; Silva, F. H.; Abreu, H. A.; Diniz, R.; J. Coord. Chem. 2015, 68, 1282.

11. de Gracia, C. G.; Burns 2001, 27, 67 .

12. Klasen, H. J.; Burns 2000, 26, 131.

13. Nomiya, K.; Yokoyama, H.; J. Chem. Soc., Dalton Trans. 2002, 12, 2483.

14. Nomiya, K.; Kondoh, Y.; Onoue, K.; Kasuga, N. C.; Nagano, H.; Oda, M.; Sudoh, T.; Sakuma, S.; J. Inorg. Biochem. 1995, 58, 255.
15. Mjos, K. D.; Orvig, C.; Chem. Rev. (Washington, DC, U. S.) 2014, 114, 4540.

16. Berners-Price, S. J.; Johnson, R. K.; Giovenella, A. J.; Faucette, L. F.; Mirabelli, C. K.; Sadler, P. J.; J. Inorg. Biochem. 1988, 33, 285.

17. Klasen, H. J.; Burns 2000, 26, 117.

18. Nomiya, K.; Noguchi, R.; Oda, M.; Inorg. Chim. Acta 2000, 298, 24.

19. Nomiya, K.; Noguchi, R.; Shigeta, T.; Kondoh, Y.; Tsuda, K.; Ohsawa, K.; Chikaraishi-Kasuga, N.; Oda, M.; Bull. Chem. Soc. Jpn. 2000, 73, 1143.

20. Wang, H.; Wang, M.; Yang, X.; Xu, X.; Hao, Q.; Yan, A.; Hu, M.; Lobinski, R.; Li, H.; Sun, H.; Chem. Sci. 2019, 10, 7193.

21. Wang, H.; Yan, A.; Liu, Z.; Yang, X.; Xu, Z.; Wang, Y.; Wang, R.; KoohiMoghadam, M.; Hu, L.; Xia, W.; Tang, H.; Wang, Y.; Li, H.; Sun, H.; PLoS Biol. 2019, 17, e3000292.

22. Matsui, Y.; Otomo, K.; Ishida, S.; Yanagihara, K.; Kawanobe, Y.; Kida, S.; Taruoka, E.; Sugawara, I.; Microbiol. Immunol. 2004, 48, 489.

23. Manzano, C. M.; Nakahata, D. H.; Tenorio, J. C.; Lustri, W. R.; Resende Nogueira, F. A.; Aleixo, N. A.; da Silva Gomes, P. S.; Pavan, F. R.; Grecco, J. A.; Ribeiro, C. M.; Corbi, P. P.; Inorg. Chim. Acta 2020, 502, 119293.

24. Montelongo-Peralta, L. Z.; León-Buitimea, A.; Palma-Nicolás, J. P.; Gonzalez-Christen, J.; Morones-Ramírez, J. R.; Sci. Rep. 2019, 9, 5471.

25. Palomino, J.-C.; Martin, A.; Camacho, M.; Guerra, H.; Swings, J.; Portaels, F.; Antimicrob. Agents Chemother. 2002, 46, 2720.

26. Becke, A. D.; J. Chem. Phys. 1993, 98, 5648.

27. Lee, C.; Yang, W.; Parr, R. G.; Phys. Rev. B 1988, 37, 785.

28. Vosko, S. H.; Wilk, L.; Nusair, M.; Can. J. Phys. 1980, 58, 1200.

29. Ditchfield, R.; Hehre, W. J.; Pople, J. A.; J. Chem. Phys. 1971, 54, 724.

30. Hehre, W. J.; Ditchfield, R.; Pople, J. A.; J. Chem. Phys. 1972, 56, 2257.

31. Hariharan, P. C.; Pople, J. A.; Theor. Chim. Acta 1973, 28, 213.

32. Hay, P. J.; Wadt, W. R.; J. Chem. Phys. 1985, 82, 270.

33. Frisch, J.; Trucks, G. W.; Schlegel, H. B.; Scuseria, G. E.; Robb, M. A.; Cheeseman, J. R.; Scalmani, G.; Barone, V.; Mennucci, B.; Petersson, G. A.; Nakatsuji, H.; Caricato, M.; Li, X.; Hratchian, H. P.; Izmaylov, A. F.; Bloino, J.; Zheng, G.; Sonnenberg, J. L.; Hada, M.; Ehara, M.; Toyota, K.; Fukuda, R.; Hasegawa, J.; Ishida, M.; Nakajima, T.; Honda, Y.; Kitao, O.; Nakai, H.; Vreven, T.; Montgomery, J. A.; Peralta, J. E.; Ogliaro, F.; Bearpark, M.; Heyd, J. J.; Brothers, E.; Kudin, K. N.; Staroverov, V. N.; Kobayashi, R.; Normand, J.; Raghavachari, K.; Rendell, A.; Burant, J. C.; Iyengar, S. S.; Tomasi, S.; Cossi, M.; Rega, N.; Millam, J. M.; Klene, M.; Knox, J. E.; Cross, J. B.; Bakken, V.; Adamo, C.; Jaramillo, J.; Gomperts, R.; Stratmann, R. E.; Yazyev, O.; Austin, A. J.; Cammi, R.; Pomelli, C.; Ochterski, J. W.; Martin, R. L.; Morokuma, K.; Zakrzewski, V. G.; Voth, G. A.; Salvador, P.; Dannenberg, J. J.; Dapprich, S.; Daniels, A. D.; Farkas, Ö.; Foresman, J. B.; Ortiz, J. V.; Cioslowski, J.; Fox, D. J.; Gaussian 09, Revision D.1; Gaussian, Inc., Wallingford CT, 2016.

34. Bader, R. F. W.; Atoms in molecules: a quantum theory, 1st ed., Clarendon Press: Wotton-under-Edge, 1994.

35. Ribeiro, I.; Reis, D.; Pereira, D.; J. Mol. Model. 2019, 25, 267

36. Keith, T.A.; AIMA11 (Version 17.11.14); Overland Park, USA, 2017.

37. Borba, A.; Gómez-Zavaglia, A.; Fausto, R.; J. Chem. Phys. A 2009, 113, 9220.

38. Nakamoto, K.; Infrared and Raman spectra of inorganic and coordination compounds, $5^{\text {th }}$ ed., Wiley: New York, 1997.

39. Goebbert, D. J.; Garand, E.; Wende, T.; Bergmann, R.; Meijer, G.; Asmis, K. R.; Neumark, D. M.; J. Phys. Chem. A 2009, 113, 7584.

40. Hanson, J. C.; Camerman, N.; Camerman, A.; J. Med. Chem. 1981, 24 , 1369.

41. Oliveira, J.; Sousa, E.; Basso, L.; Palaci, M.; Dietze, R.; Santos, D.; Moreira, I.; Chem. Commun. 2004, 10, 312.

42. Ahmed, M.; Rooney, D.; McCann, M.; Devereux, M.; Twamley, B.; Galdino, A. C. M.; Sangenito, L. S.; Souza, L. O. P.; Lourenço, M. C.; Gomes, K.; Santos, A. L. S.; BioMetals 2019, 32, 671. 